\title{
Acute Budd-Chiari syndrome with hepatic failure and obstruction of the inferior vena cava as presenting manifestations of hereditary protein $\mathrm{C}$ deficiency
}

\author{
M Bourlière, Y P Le Treut, D Arnoux, P Castellani, L Bordigoni, A Maillot, M Antoni, \\ D Botta, B Pol, A P Gauthier
}

\begin{abstract}
The protein $\mathbf{C}$ system is essential in limiting the activation of coagulation in vivo. We report on a 29 year old woman with Budd-Chiari syndrome and occlusion of the inferior vena cava who presented with acute liver failure. She was successfully treated with an emergency mesoatrial shunt. Eight months after surgery, she has no ascites and normal liver function. She had a low concentration of plasma protein $C$ on admission to hospital and during the follow up. Protein C deficiency subsequently was found in her father and two sisters, who were asymptomatic. Hereditary protein $\mathrm{C}$ deficiency should be considered in patients with Budd-Chiari syndrome.
\end{abstract}

Budd-Chiari syndrome is a rare disorder whose cause remains unknown in one third of patients. ${ }^{12}$ This syndrome has, however, been associated with a variety of conditions including malignancy, ${ }^{1-7}$ treatment for malignancy, ${ }^{8-9}$ polycythaemia rubra vera, ${ }^{10}$ paroxysmal nocturnal haemoglobinuria, ${ }^{11}$ other primary myeloproliferative disorders, ${ }^{12}$ pregnancy, ${ }^{13,14}$ hepatic amoebiasis, ${ }^{15}$ oral contraceptives, ${ }^{16}$ and less usual causes such as ingestion of pyrrolizidine alkaloid-containing teas, ${ }^{17}$ aspergillus infections,${ }^{18}$ hydatid cysts, ${ }^{12}$ antithrombin III deficiency, ${ }^{19} 20$ and Behçet disease. ${ }^{21} 22$

Protein $\mathrm{C}$ is a major factor regulating thrombin generation. Hereditary deficiency in protein $\mathrm{C}$ is associated with a high risk of thrombotic disease. ${ }^{23}$ Manifestations include superficial thrombophlebitis, deep venous thrombosis or pulmonary embolism, or both, ${ }^{23-24}$ cerebral venous thrombosis, ${ }^{25}$ and splanchnic venous thrombosis. ${ }^{26-30}$

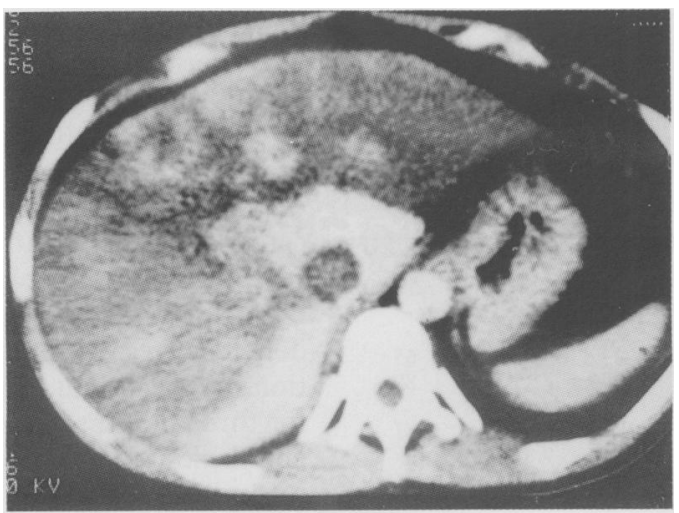

Protein $\mathrm{C}$ is a vitamin $\mathrm{K}$-dependent zymogen of a serine protease ${ }^{31}$ and is synthesised in the liver. ${ }^{32}$ It is converted to its activated form in a reaction catalysed by a complex formed between thrombin and thrombomodulin, an endothelial cell surface protein. ${ }^{33}$ Activated protein $\mathrm{C}$ inhibits activated factors $\mathrm{V}$ and VIII ${ }^{34}$ and stimulates fibrinolysis through the inactivation of the tissue plasminogen activator (t-PA) inhibitor. ${ }^{35}$

We present the first case of acute hepatic vein thrombosis in a patient with a history of oral contraceptive usage and recent recurrent orogenital ulcers associated with hereditary protein C deficiency.

\section{Case report}

On 17 November 1988, a 29 year old Algerian woman was admitted to our liver unit with acute liver failure and ascites. There was no familial or personal history of venous thrombosis despite three previous surgical procedures 10, five, and three years earlier. In 1985 she had a normal labour and delivery. She had taken oral contraceptives from 1979 to 1984 without any problems and for three months before admission to hospital. From April 1988, the patient reported a history of recurrent orogenital ulcers.

On 2 November 1988, the patient began to suffer abdominal pain and general fatigue. Eight days later she presented to her physician with painful hepatomegaly, ascites, and bilateral leg oedema. Laboratory data disclosed an alanine aminotransferase activity of $150 \mathrm{IU}$ (normal less than $33 \mathrm{IU}$ ), and a prothrombin time ratio of $58 \%$.

On admission to hospital eight days later, clinical examination showed painful hepatomegaly, ascites, and bilateral leg oedema. There was no encephalopathy. Laboratory tests gave the following results: erythrocyte count $4.65 \times 10^{\%} / 1$, haemoglobin concentration $13.5 \mathrm{~g} / \mathrm{dl}$, leucocyte count $13.8 \times 10^{6} / 1$ with normal differential, platelet count $218 \times 10^{6} / 1$, alanine aminotransferase $992 \mathrm{IU} / \mathrm{l}$, serum total bilirubin $32 \mu \mathrm{mol} / \mathrm{l}$, serum alkaline phosphatase $187 \mathrm{IU} / 1$ (normal less than $230 \mathrm{IU}$ ), serum albumin $2.9 \mathrm{~g} / \mathrm{dl}$, serum globulin $1 \cdot 3 \mathrm{~g} / \mathrm{dl}$, prothrombin time ratio $28 \%$, and factor V $20 \%$. Serological tests for hepatitis virus A and B, Epstein-Barr virus, and cytomegalovirus were negative. Ultrasound examination showed ascites, occluded hepatic veins, and patent portal vein. The caudate lobe was not enlarged and the inferior vena cava could not be identified, suggesting an occlusion. 
Figure 2: Postoperative abdominal computed tomogram showing a patent shunt, normal liver, and partial obstruction of the inferior vena cava.

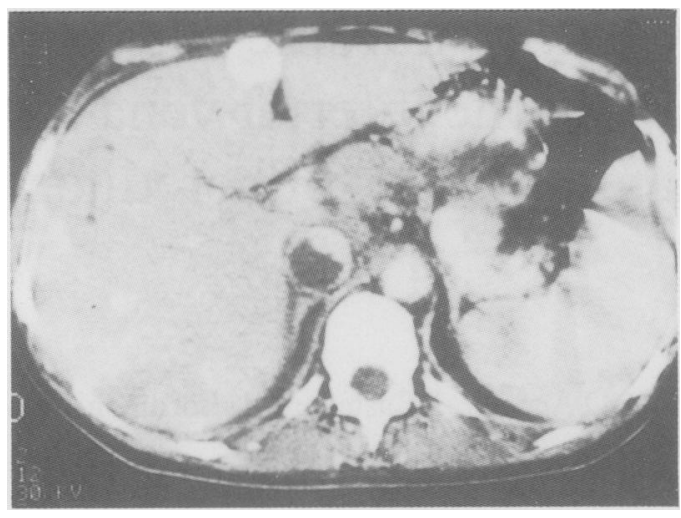

Abdominal computed tomogram confirmed the hepatic venous obstruction and showed an enlarged liver with heterogeneous uptake (Fig 1). A right transfemoral venacavogram confirmed the total obstruction of the inferior vena cava at and under its intrahepatic portion.

On 18 November 1988, the patient underwent emergency surgery because of a rapid increase in the serum transaminase activities and growing deterioration of liver function. Some 21 of ascites were drained. The liver was massively enlarged and congested, with 'dark' patches. The portal vein pressure was $39 \mathrm{~cm} \mathrm{H}_{2} \mathrm{O}$ and the superior vena cava pressure was $3 \mathrm{~cm} \mathrm{H} \mathrm{H}_{2} \mathrm{O}$. A mesoatrial shunt was created using a polytetrafluoroethylene (PTFE Gore-tex) reinforced prosthesis $14 \mathrm{~mm}$ in diameter. The graft extended from the superior mesenteric vein through the transverse mesocolon and then posteriorly to the stomach and anteriorly to the liver. A right anterolateral thoracotomy was made, the graft was placed across the anterior mediastinum, and then an end to side anastomosis was created into the right atrial appendage. Once the graft was in position and the blood flow was established, the portal vein pressure fell to $13 \mathrm{~cm} \mathrm{H}_{2} \mathrm{O}$ and the liver reduced in size.

The patient's postoperative course was uneventful, except for a right pleural effusion that persisted for one week. Ascites did not recur and all liver function tests were normal two weeks after surgery. Postoperative abdominal computed tomography showed a patent shunt and a normal liver (Fig 2). The patient was treated with intravenous sodium heparin and subsequently with coumarin.

In February 1989, the patient was readmitted because of fever and recurrent orogenital ulcers. Clinical examination was normal. There was no skin involvement, no cutaneous hyperreactivity, no arthritis, gastrointestinal, or

Results of coagulation studies in the proband and three affected members of her family

\begin{tabular}{|c|c|c|c|c|c|c|}
\hline & \multirow{2}{*}{$\begin{array}{l}\text { Normal } \\
\text { range } \\
(\%)\end{array}$} & \multicolumn{2}{|c|}{ Proband $(I I-I)$} & \multicolumn{3}{|c|}{ Family members } \\
\hline & & $\begin{array}{l}11 / 88 \\
(\%)\end{array}$ & $\begin{array}{l}02 / 89 \\
(\%)\end{array}$ & $\begin{array}{l}(I-1) \\
(\%)\end{array}$ & $\begin{array}{l}(I I-2) \\
(\%)\end{array}$ & $\begin{array}{l}(I I-4) \\
(\%)\end{array}$ \\
\hline $\begin{array}{l}\text { Factor II } \\
\text { Factors VII + X } \\
\text { Factor V } \\
\text { Protein C antigen } \\
\text { Protein C activity } \\
\text { Protein S antigen } \\
\text { Plasminogen activity } \\
\text { Heparin cofactor II activity } \\
\text { Antithrombin III activity } \\
\text { Fibrinogen }(\mathrm{g} / \mathrm{l})\end{array}$ & $\begin{array}{l}70-120 \\
70-120 \\
70-120 \\
70-140 \\
70-140 \\
70-140 \\
80-120 \\
65-120 \\
80-120 \\
2-4\end{array}$ & $\begin{array}{l}46 \\
26 \\
20 \\
\\
40 \\
70\end{array}$ & $\begin{array}{l}70 \\
70 \\
80 \\
40 \\
36 \\
70 \\
90 \\
65 \\
90 \\
3 \cdot 10\end{array}$ & $\begin{array}{c}53 \\
90 \\
124 \\
80 \\
2 \cdot 30\end{array}$ & $\begin{array}{c}57 \\
70 \\
90 \\
100 \\
2 \cdot 10\end{array}$ & $\begin{array}{c}65 \\
80 \\
\\
87 \\
100 \\
2 \cdot 20\end{array}$ \\
\hline
\end{tabular}

occular manifestation of Behçet syndrome. Ultrasound examination and abdominal computed tomogram failed to detect any new vascular lesion and the shunt remained patent.

Laboratory data were normal. We were unable to find any major or minor signs of Behçet syndrome other than orogenital ulcers and deep venous thrombosis.

Eight months after surgery the patient is well and Doppler ultrasound confirms the patency of the mesoatrial shunt.

During her stay in hospital, before and after surgery the search for a myeloproliferative disease was negative, but culture of bone marrow cells was not undertaken. There was no laboratory evidence of paroxysmal nocturnal haemoglobinuria or lupus anticoagulant. As shown in the Table, a type I protein $\mathrm{C}$ deficiency was found, ${ }^{36}$ as functional and immuno-enzymatic assays gave low values for plasma protein C. There was no deficiency in protein S, antithrombin III, plasminogen, or heparin cofactor II, and the fibrinolytic tests were normal.

A study of the patient's family (Fig 3), showed deficiency in protein $C$ in the father of the proband (I-2) and two out of her three sisters (II-2 and II-4). All were asymptomatic except one sister (II-2), who had varicose veins.

\section{Discussion}

Protein $\mathrm{C}$ deficiency can be inherited and is then most often transmitted as an autosomal dominant trait with various penetrance. ${ }^{232626} \mathrm{~A}$ low protein $\mathrm{C}$ value can also be acquired as a result of disseminated intravascular coagulation, ${ }^{37}$ which was not present in any of the affected members of this family and was present in our patient only at the time of her first hospital admission and not later. Protein $\mathrm{C}$ deficiency is more commonly the consequence of liver disease, when it is associated with decreased values of other coagulation factors. Impairment of liver function, which results from Budd-Chiari syndrome, could account for the low protein $C$ value in our patient at hospital admission, but not three months after surgery (Table) as her liver function tests and the values of other coagulation factors were normal then. In this family, protein C deficiency was found in two asymptomatic young women, in one asymptomatic man, and in the proband. Thus protein $\mathrm{C}$ deficiency detected in the propositus is compatible with a defect inherited as an autosomal dominant trait.

Heterozygous protein $\mathrm{C}$ deficiency is an important independant risk factor for the development of thrombosis. ${ }^{38}$ However, a recent study by Miletich et al,,$^{39}$ noted that the frequency of heterozygous protein $\mathrm{C}$ deficiency may be as high as $1 / 200$ in a healthy adult population, and that biochemically affected people do not suffer a thrombotic manifestation. This study also indicates that other factors, as yet undefined, may play an important role in the clinical expression of this disorder. It is not clear whether protein $C$ deficiency was the only cause of vascular obstruction in our patient. She took oral contraceptives for three months before the initial manifestation and these could have increased the risk of venous thrombosis by adding their thrombogenic effect 


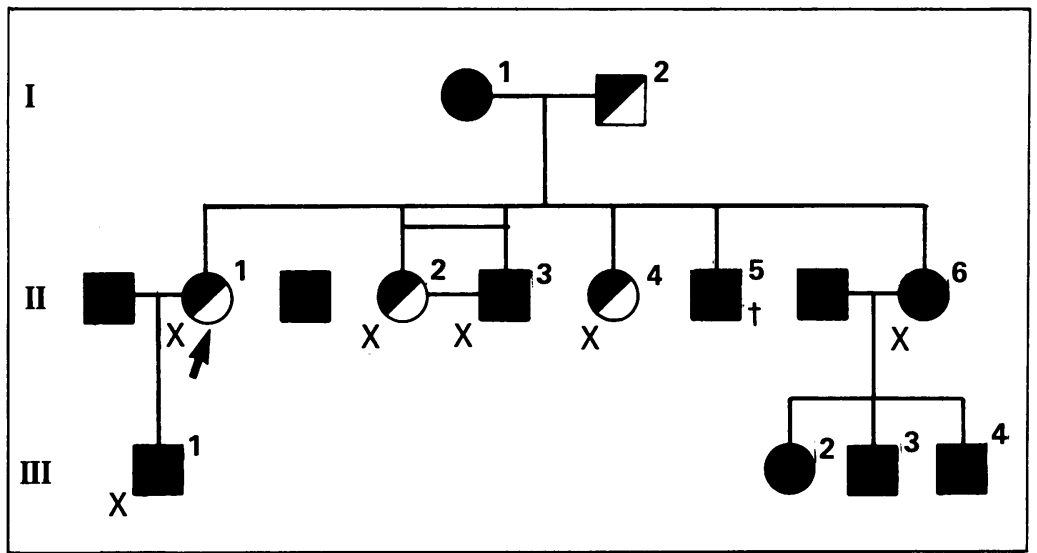

Figure 3: The patient's family. Protein $C$ deficiency was found in the father $(I-2)$ and two of the proband's (II-I) three sisters (II-2 and II-4).

to that of protein C deficiency. ${ }^{16}$ Moreover, the recent recurrent orogenital ulcers and the inferior vena cava obstruction suffered by our patient may well have been underlying conditions of a 'latent' Behçet syndrome, in which a thrombogenic effect is well known. ${ }^{21}{ }^{22}$ Protein C deficiency may not therefore have been the only thrombogenic condition in our patient.

The estimated prevalence of protein $\mathrm{C}$ deficiency in portal vein thrombosis is $2 \%,{ }^{29}$ higher than the figure reported for thrombosis of unselected site. ${ }^{23}{ }^{24}$ We suggest that values of protein $\mathrm{C}$, as well as those of protein $\mathrm{S}$ and antithrombin III, should be measured in patients with splanchnic venous thrombosis, even when another cause is present.

Prevention of recurrent thrombosis by coumarin derivatives is mandatory in patients with hereditary protein $\mathrm{C}$ deficiency. Conventional medical management of acute Budd-Chiari syndrome is often unsuccessful. ${ }^{21+041}$ Mesoatrial shunt is the treatment of choice for acute BuddChiari syndrome in which there is complete obstruction of the inferior vena cava, ${ }^{+0+2+3}$ despite a conflicting long term prognosis. ${ }^{42+3}$ Orthotopic liver transplantation with adjunctive anticoagulant medication may also be considered as an alternative treatment choice,,$^{41}$ particularly in patients with metabolic liver disorders such as protein $\mathrm{C}$ deficiency ${ }^{44}$ and when the course of the disease shows chronic hepatic failure. ${ }^{+1}$ The obstruction of the inferior vena cava and the recent and rapid onset of the disease led us to use a mesoatrial shunt as a first line method. Further studies will help to determine the best procedure to be followed.

We are particularly grateful to Miss Rocca for expert technical assistance.

1 Parker RGF. Occlusion of the hepatic veins in man. Medicine (Baltimore) 1959; 38: 369-402

2 Mitchell MC, Boitnott JK, Kaufman S, Cameron JL, Maddrey WC. Budd-Chiari syndrome: etiology, diagnosis and management. Medicine (Baltimore) 1982; 61: 199-218.

3 Justiniani FR, Cohen GH, Roen SA, Anibas I, Kushner DS. Budd-Chiari syndrome due to leiomyosarcoma of the inferior vena cava. Am $\mathcal{F}$ Dig Dis 1973; 18: 337-46.

4 Lin JI, Chang CH, Tseng C. Budd-Chiari syndrome caused by undifferentiated small round cell tumor of the liver in an undiff. Hum Pathol 1979; 10: 475-8.

5 Michael J, Desmond AD, Jackson BT, Thompson RP. Occlusion of the hepatic veins by an adrenal carcinoma. Occlusion of the hepatic veins by an
Am 7 Gastroenterol 1978; 69: 599-600.

6 Okulski TA, Soulen RL. Renal cell carcinoma presenting as the Budd-Chiari syndrome. Am $\mathcal{F}$ Roentgenol 1977; 128: $140-2$.
7 Theodossi A, Al-Ashbel AA, Dische FE, Pryor JS, Williams $R$. Budd-Chiari syndrome from myosarcoma of the right R. Budd-Chiari syndrome from my
atrium. F Pathol 1979; 128: 159-62.

8 Berk PD, Popper H, Krueger GR, et al. Veno-occlusive disease of the liver after allogenic bone marrow transplantation: possible association with graft-versus-host disease. Ann Intern Med 1979; 90: 158-64

9 Lehrner LM, Enck RE. Hepatic vein thrombosis after chemotherapy for histiocytoma. Ann Intern Med 1978; 88: 575-6.

10 Noble JA. Hepatic vein thrombosis complicating polycythemia vera. Successful treatment with a portocaval shunt. Arch Intern Med 1967; 120: 105-8.

11 Valla D, Dhumeaux D, Babany G, et al. Hepatic vein thrombosis in paroxysmal nocturnal hemoglobinuria. Gastroenterology 1987; 93: 569-75.

12 Valla D, Casadevall N, Lacombe C, et al. Primary myeloproliferative disorder and hepatic vein thrombosis. A prospective study of erythroid colony formation in vitro in 20 patients with Budd-Chiari syndrome. Ann Intern Med 1985; patients with

13 Khuroo MS, Datta DV. Budd-Chiari syndrome following pregnancy. Am F Med 1980; 68: 113-21.

14 Rosenthal T, Shani M, Deutsch V, et al. The Budd-Chiari syndrome after pregnancy: report of two cases and a review of the literature. Am f Obstet Gynecol 1972; 113: 789-92.

15 Langer B, Stone RM, Colapinto RF, et al. Clinical spectrum of the Budd-Chiari syndrome and its surgical management. $\mathrm{Am}$ $\mathcal{F}$ Surg 1975; 129: 137-45.

16 Valla D, Le MG, Poynard T, Zucman N, Rueff B, Benhamou JP. Risk of hepatic vein thrombosis in relation to recent use of oral contraceptives: a case-control study. Gastroenterology 1986; 90: 807-11.

17 Tandon BN, Tandon HD, Tandon TK, et al. An epidemic of veno-occlusive disease of the liver in central India. Lancet 1976; i: $271-2$.

18 Young RC. The Budd-Chiari syndrome caused by aspergillus: two patients with vascular invasion of hepatic veins. Arch Intern Med 1969; 124: 754-7.

19 McClure S, Dincsoy HP, Glueck H. Budd-Chiari syndrome and antithrombin III deficiency. Am F Clin Pathol 1982; 78: $236-41$.

20 Das M, Carroll SF. Antithrombin III deficiency: An etiology of Budd-Chiari syndrome. Surgery 1985; 97: 242-5.

21 Le Treut YP, Comiti Y, Bremondy A, et al. Syndrome de Budd-Chiari et maladie de Behçet. Une observation traitée par prothése mésentérico-atriale. Gastroenterol Clin Biol 1988; 12: 265-9.

22 Wilkey D, Yocum DE, Oberley TD, Sundstrom WR, Karl L. Budd-Chiari syndrome and renal failure in Behçet disease. Am F Med 1983; 75: 541-50.

23 Bertina RM, Broekmans AW, Van Der Linden IK, Mertens $\mathrm{K}$. Protein $\mathrm{C}$ deficiency in a Dutch family with thrombotic disease. Thromb Haemost 1982; 48: 1-5.

24 Horellou MH, Conard J, Bertina RM, Samama M. Congenital protein $\mathrm{C}$ deficiency and thrombotic disease in nine French families. $B r M e d \mathcal{F} 1984 ; 289$ : 1285-7.

25 Wintzen AR, Broekmans AW, Bertina RM, et al. Cerebral haemorrhagic infarction in young patients with hereditary protein $\mathrm{C}$ deficiency: evidence for 'spontaneous' cerebral venous thrombosis. $\mathrm{Br}$ Med f 1985; 290: 350-2.

26 Pabinger-Fasching I, Bertina RM, Lechner K, Niessner $H$, Korninger C. Protein C deficiency in two Austrian families. Thromb Haemost 1983; 50: 810-3.

27 Lefrancois C, Derlon A, Sillard B, Leroy G, Marchand P. Deficit constitutionnel en proteine $C$. Rôle dans la survenue d'un infarctus veineux mésentérique. Presse Med 1985; 14: d'un info.

28 Green D, Ganger DR, Blei A. Protein C deficiency in splanchnic venous thrombosis. Am F Med 1987; 82: 1171-4.

29 Valla D, Denninger MH, Delvigne JM, Rueff B, Benhamou JP. Portal vein thrombosis with ruptured oesophageal varices as presenting manifestation of hereditary protein $\mathrm{C}$ deficiency. Gut 1988; 29: 856-9.

30 Orozco H, Guraieb E, Takahashi T, et al. Deficiency of protein $\mathrm{C}$ in patient with portal vein thrombosis. Hepatology $1988 ; 8$ : 1110-1.

31 Stenflo J. A new vitamin K-dependent protein: purification from bovine plasma and preliminary characterization. $\mathcal{F ~ B i o l ~}$ Chem 1976; 251: 355-63.

32 Fair DS, Marlar SA. Biosynthesis and secretion of factor VII, protein $C$, protein $S$, and the protein $C$ inhibitor from a protein C, protein S, and the protein C inhibitor

33 Owen WG, Esmon CT. Functional properties of an endothelial cell cofactor for thrombin. Catalyzed activation of protein C. F Biol Chem 1981; 256: 5532-5.

34 Marlar RA, Kleiss AJ, Griffin JH. Human protein C: inactivation of factor $\mathrm{V}$ and VIII in plasma by the activated molecule. Ann NY Acad Sci 1981; 370: 303-10.

35 Sakata Y, Curriden S, Lawrence D, Griffin JH, Loskutoff DJ. Activated protein $\mathrm{C}$ stimulates the fibrinolytic activity of cultured endothelial cells and decreases antiactivator activity. Proc Natl Acad Sci USA 1985; 82: 1121-5.

36 Bertina RM, Broekmans AW, Kommenhoek-Van EsC, Van Wijngaarden $\mathrm{A}$. The use of a functional and immunologic assay for plasma protein $\mathrm{C}$ in the study of heterogeneity of congenital protein C deficiency. Thromb Haemost 1984; 51: $1-5$.

37 Griffin JH, Mosher DF, Zimmerman TS, Kleiss AT. Protein $\mathrm{C}$, an antithrombotic protein, is reduced in hospitalized patients with intravascular coagulation. Blood 1982; 60: patients

38 Bovill EG, Bauer KA, Dickerman JD, Callas P, West B. The clinical spectrum of heterozygous protein $C$ deficiency in a clinical spectrum of heterozygous protein $\mathrm{C}$ deficie

39 Miletich J, Sherman L, Broze G Jr. Absence of thrombosis in 
subjects with heterozygous protein $\mathrm{C}$ deficiency. $\mathrm{N} \mathrm{Engl} \mathcal{F}$ Med 1987; 317: 991-6.

40 Millikan WJ, Henderson JM, Sewell CW, et al. Approach to the spectrum of Budd-Chiari syndrome: Which patients require portal decompression? Am f Surg 1985; 149: 167-76.

41 Campbell DA, Rolles K, Jamieson N, et al. Hepatic transplantation with perioperative and long term anticoagulation as treatment for Budd-Chiari syndrome. Surg Gynecol Obstet 1986; 166: 511-8.
42 Cameron JL, Herlong HF, Sanfey H, et al. The Budd-Chiari syndrome: treatment by mesenteric-systemic venous shunts. Ann Surg 1983; 198: 335-46.

43 Vons C, Bourstyn E, Bonnet P, Smadja C, Szekely AM Franco D. Results of portal systemic shunts in Budd-Chiari Franco D. Results of portal systemic shunts in Budd-Chiari

44 Casella JF, Lewis JH, Bontempo FA, Zitelli BJ, Markel H, Starzl TE. Successful treatment of homozygous protein $C$ deficiency by hepatic transplantation. Lancet 1988; i: $435-8$ 